\title{
Detection of Bartonella alsatica in European wild rabbit and their fleas (Spilopsyllus cuniculi and Xenopsylla cunicularis) in Spain
}

\author{
Francisco J Márquez
}

\begin{abstract}
Background: Bartonella alsatica has been formerly isolated from the blood of wild European rabbit (Oryctolagus cuniculus) and identified as causative agent of human endocarditis and lymphadenitis. Fleas are known biological vectors for Bartonella sp. This report details the specific detection of B. alsatica in three flea species commonly associated with the European wild rabbit in Southern Iberian Peninsula (Odontopsyllus quirosi, Spylopsyllus cuniculi and Xenopsylla cunicularis).
\end{abstract}

Methods: In the present study we have tested the presence of Bartonella alsatica in 26 European wild rabbit specimens and the fleas that they carrying at the moment of capture. Together to rabbits, captured from different localities of Andalusia (Jaen, Granada and Cordoba provinces), we evaluated three of fleas species that parasitize it usually using molecular techniques [PCR amplification and sequencing of intergenic transcribed spacer (ITS) 16S-23S rRNA].

Results: Over a sample of 26 wild rabbits carrying fleas, positive PCR amplicons for B. alsatica were obtained from 10 rabbits. All positive flea pools for B. alsatica were collected from positive rabbits [33.33\% (8/24 pools) of S. cuniculi, 33.33\% (5/15 pools) of $X$. cunicularis and $0 \%$ (0/7 pools) of O. quirosi]. In three positive rabbits, a pool of S. cuniculi and two pools of $X$. cunicularis respectively were negative. After sequencing, only B. alsatica (Genbank accession AF312506) was found in the rabbits sampled as well as in $S$. cuniculi and $X$. cunicularis within the respective fleas.

Conclusions: This research confirms the implication of two pulicidae flea species, S. cuniculi and X. cunicularis in the maintenance of infection by $B$. alsatica in wild rabbit populations throughout the year. The zoonotic character of this bartonellosis emphasizes the need to alert public health authorities and the veterinary community for the risk of infection.

Keywords: Andalusia, Bartonella alsatica, Fleas, ITS, European wild rabbit, Odontopsyllus quirosi, Spilopsyllus cuniculi, Xenopsylla cunicularis, Spain

\section{Background}

Fleas carry and spread several bacterial diseases $[1,2]$ of which Bartonella spp. are a facultative intracellular bacteria typically transmitted by blood-sucking arthropods, that cause characteristic host-restricted hemotropic infections in mammals [3]. Bartonella alsatica has been formerly isolated from the blood of wild European rabbit (Oryctolagus cuniculus) in Alsace Department, France [4]. In the previous years it has been also identified within a French study as causative agent of human endocarditis and lymphadenitis [5-7].

Correspondence: jmarquez@ujaen.es

Departamento de Biología Animal, Biología Vegetal y Ecología. Facultad

Ciencias Experimentales, Universidad de Jaén, Campus Las Lagunillas s/n, 23071 Jaén, Spain
The blood feeding behavior of some arthropods plays a critical role in the transmission and maintenance of vector-borne pathogens in natural systems [8]. The application of molecular techniques for the detection of Bartonella foci has proven useful in the determination of vectorial capacity; furthermore molecular techniques used as a detection tool for fleas infected with Bartonella caught in nature is an essential tool for establishing a link between potential vectors and pathogens [9], whereas detection of DNA alone can be used as a preliminary step in determining which fleas are potential vectors and should be further studied.

Ectoparasites of European wild rabbit have provided insights into co-evolutionary processes between hosts 
[10-12]. The research governing the evolution of hostparasite interactions was discovered in the Iberian Peninsula and the South of France [13]. Five flea species were found on wild rabbits in Iberian Peninsula: Spilopsyllus cuniculi (Dale, 1878), Xenopsylla cunicularis Smit, 1957, Odontopsillus quirosi (Gil Collado, 1934), Caenopsylla laptevi ibera Beaucournu \& Márquez, 1987, and Echidnophaga iberica Ribeiro et al., 1994. Spilopsyllus cuniculi and $X$. cunicularis were the most prevalent and largely distributed fleas over rabbit populations [14]. The development and distribution of fleas, especially S. cuniculi, can be affected by the environment within the rabbit's burrows [15,16]. Molecular detection of $B$. alsatica (taken from ear pinnae) has been recently reported with a prevalence of $17.2 \%$ over a large sample of wild rabbits in Southern areas of Iberian Peninsula [17].

\section{Methods}

The presence of Bartonella alsatica in 26 European wild rabbit specimens were tested with all respective fleas that were found carried at the moment of capture. The rabbit specimens were captured from different localities of Andalusia (Jaen, Granada and Cordoba provinces) and evaluated. In these samples three flea species that typically parasitize rabbits has been found (Spilopsyllus cuniculi, Xenopsylla cunicularis and Odontopsyllus quirosi). Fleas collected from wild rabbits were suspended in a solution of $70 \%$ ethanol diluted with sterile water and stored in a refrigerator until ready for use. Flea species identification was performed using a regional taxonomic identification key [11]. Studied were 197 fleas distributed by host and species. Considered were 113 S. cuniculi $(20$ males, 93 females) in 24 pooled flea samples (average of 4.71 fleas per pool), $71 \mathrm{X}$. cunicularis ( 21 males, $50 \mathrm{fe}-$ males) distributed in 15 pools (average of 4.73 fleas per pool) and 13 O. quirosi (5 males, 8 females) distributed in 7 pools (average of 1.87 fleas per pool) (Table 1).

DNA from spleen of wild European rabbits and its fleas was extracted using the Macherey-Nagel DNA tissue Kit (Düren, Germany), according to the manufacturer's instructions. During DNA extraction negative controls consisting of sterile water were included for every 15 samples. DNA extracts were stored at $-20^{\circ} \mathrm{C}$ until further processing. DNA from each pool of fleas was tested by PCR using the primers, URBarto $1\left(5^{\prime}-\mathrm{C}\right.$ TT CGT TTC TCT TTC TTC A) [18] and Balsatrev1 (5' - CTT CTC TTC ACA ATT TCA TT) [17] for the first amplification round, and Balsatfor2 $\left(5^{\prime}\right.$ - CGT TTC TCT TTC TTC AGA TG) and Balsatrev2 (5' - TCA CAA TTT CAT TAG AAC AAG) [17], which amplify specifically a fragment of the 16S-23S rRNA intergenic spacer region (ITS) of the B. alsatica. As negative control, in addition to extraction blanks, DNA from five wild rabbits, five pools of Ctenocephalides felis and four pools of Pulex irritans fleas, all negative for B. alsatica, has been included [19]. To test the presence of other Bartonella species in the studied samples we used other primer system as previously described [19]. To avoid PCR contamination, sample preparation, reactions setup, and PCR amplifications were carried out in separate laboratories, with different lab coats and gloves.

PCR amplifications were carried out in a MJ Mini Personal Thermal Cycler (Biorad, Hercules, CA, USA). Each first PCR mixture round consisted of the following: $8 \mu \mathrm{l}$ of DNA, 20 pmol of each primer, $200 \mu \mathrm{M}$ of dATP, dCTP, dTTP, dGTP, $2.0 \mathrm{mM} \mathrm{MgCl} 2,0.033 \mathrm{U}$ of DNA polymerase in 1x Taq buffer advanced (5 Prime GmbH, Hamburg, Germany), and sterile distilled water to a final volume of $50 \mu \mathrm{L}$. PCR cycles included an initial 90 seconds denaturation step at $96^{\circ} \mathrm{C}$, followed by 25 and 30 cycles, for first and second amplification rounds, of denaturation at $94^{\circ} \mathrm{C}$ for 30 seconds, annealing at 50 and $52^{\circ} \mathrm{C}$ for 30 seconds, and extension at $68^{\circ} \mathrm{C}$ for 60 seconds. Amplification was completed by holding the reaction mixture at $68^{\circ} \mathrm{C}$ for 7 minutes to allow complete extension.

As flea internal DNA quality control and to help in the molecular identification of fleas species, PCR amplification of a $658 \mathrm{bp}$ fragment of the mitochondrial cytochrome c oxidase subunit I (COI) gene was done with the same conditions expressed above and standard DNA barcoding primers LCO-1490 F 5'-GGT CAA CAA ATC ATA AAG ATA TTG G and HCO-2198R 5' - TAA ACT TCA GGG TGA CCA AAA AAT CA [20] using an annealing temperature of $46^{\circ} \mathrm{C}$.

PCR products were resolved by electrophoresis in 1.0\% SeaKem agarose (Cambrex, Rockland, ME, USA) in $1 \times$ buffer Bionic (Sigma, St. Louis, MO, USA) gels using a $100 \mathrm{bp}$ ladder as molecular weight marker (Eurogentec, Seraing, Belgium). Products containing positive results were purified by using the Montage PCR kit (Millipore, Bedford, MA, USA) prior to sequencing. Positive PCR products were sequenced using PCR primers and the GenomeLab DTCS- Quick Start kit (Beckman Coulter) and a CEQ 2000XL capillary DNA sequencer (Beckman Coulter) according to the manufacturer's instructions. The resulting ITS sequences were manually aligned and analyzed with Bioedit vers. 7.0.1. sequence analysis software [21] to obtain consensus sequences and to align and compare other Bartonella alsatica sequences found on GenBank, including previously sequenced and identified species of Bartonella, with homologous sequences obtained directly from rabbits tissues and fleas. Sequences were identified using the BLAST feature of GenBank (http://ncbi.nlm.nih.gov/blastn) [22]. PCR-derived flea COI gene sequences are deposited in GenBank under the accession numbers KF479234-KF479240 respectively for S. cuniculi (4 sequences), X. cunicularis, Echidnophaga iberica, and O. quirosi. 
Table 1 Flea pools composition

\begin{tabular}{|c|c|c|c|c|c|c|}
\hline O. cuniculus & $\Sigma$ S. cuniculi & S. c. results & $\Sigma X$. unicularis & $X$. c. results & $\Sigma 0$. quirosi & O. q. results \\
\hline Pos. & $6(1 \mathrm{M}, 5 \mathrm{~F})$ & Pos. & $7(3 \mathrm{M}, 4 \mathrm{~F})$ & Pos. & $1(1 \mathrm{M}, \mathrm{O} F)$ & Neg. \\
\hline Pos. & $4(0 \mathrm{M}, 4 \mathrm{~F})$ & Pos. & $5(2 M, 3 F)$ & Pos. & $2(1 \mathrm{M}, 1 \mathrm{~F})$ & Neg. \\
\hline Pos. & $5(0 \mathrm{M}, 5 \mathrm{~F})$ & Pos. & $6(1 \mathrm{M}, 5 \mathrm{~F})$ & Pos. & - & - \\
\hline Pos. & $6(2 \mathrm{M}, 4 \mathrm{~F})$ & Pos. & $5(3 \mathrm{M}, 2 \mathrm{~F})$ & Pos. & - & - \\
\hline Pos. & $5(1 \mathrm{M}, 4 \mathrm{~F})$ & Pos. & $4(0 \mathrm{M}, 4 \mathrm{~F})$ & Neg. & - & - \\
\hline Pos. & $5(2 \mathrm{M}, 3 \mathrm{~F})$ & Pos. & $6(1 \mathrm{M}, 5 \mathrm{~F})$ & Neg. & - & - \\
\hline Pos. & $3(0 \mathrm{M}, 3 \mathrm{~F})$ & Pos. & - & - & - & - \\
\hline Pos. & $3(0 \mathrm{M}, 3 \mathrm{~F})$ & Pos. & - & - & - & - \\
\hline Pos. & $5(2 \mathrm{M}, 3 \mathrm{~F})$ & Neg. & - & - & - & - \\
\hline Pos. & - & - & $6(2 \mathrm{M}, 4 \mathrm{~F})$ & Pos. & - & - \\
\hline Neg. & $5(0 \mathrm{M}, 5 \mathrm{~F})$ & Neg. & $4(1 \mathrm{M}, 3 \mathrm{~F})$ & Neg. & $1(1 \mathrm{M}, \mathrm{O} F)$ & Neg. \\
\hline Neg. & $6(2 \mathrm{M}, 4 \mathrm{~F})$ & Neg. & $6(2 \mathrm{M}, 4 \mathrm{~F})$ & Neg. & $3(1 \mathrm{M}, 2 \mathrm{~F})$ & Neg. \\
\hline Neg. & $6(1 \mathrm{M}, 5 \mathrm{~F})$ & Neg. & $5(2 \mathrm{M}, 3 \mathrm{~F})$ & Neg. & $1(0 \mathrm{M}, 1 \mathrm{~F})$ & Neg. \\
\hline Neg. & $3(0 \mathrm{M}, 3 \mathrm{~F})$ & Neg. & $5(0 \mathrm{M}, 5 \mathrm{~F})$ & Neg. & - & - \\
\hline Neg. & $6(2 \mathrm{M}, 4 \mathrm{~F})$ & Neg. & $3(0 \mathrm{M}, 3 \mathrm{~F})$ & Neg. & - & - \\
\hline Neg. & $7(2 \mathrm{M}, 5 \mathrm{~F})$ & Neg. & $2(0 \mathrm{M}, 2 \mathrm{~F})$ & Neg. & - & - \\
\hline Neg. & $5(1 \mathrm{M}, 4 \mathrm{~F})$ & Neg. & $3(2 \mathrm{M}, 1 \mathrm{~F})$ & Neg. & - & - \\
\hline Neg. & $4(0 \mathrm{M}, 4 \mathrm{~F})$ & Neg. & $4(2 \mathrm{M}, 2 \mathrm{~F})$ & Neg. & - & - \\
\hline Neg. & $3(0 \mathrm{M}, 3 \mathrm{~F})$ & Neg. & - & - & $3(0 \mathrm{M}, 3 \mathrm{~F})$ & Neg. \\
\hline Neg. & $2(0 \mathrm{M}, 2 \mathrm{~F})$ & Neg. & - & - & - & - \\
\hline Neg. & $4(1 \mathrm{M}, 3 \mathrm{~F})$ & Neg. & - & - & - & - \\
\hline Neg. & $5(0 \mathrm{M}, 5 \mathrm{~F})$ & Neg. & - & - & - & - \\
\hline Neg. & $6(2 \mathrm{M}, 4 \mathrm{~F})$ & Neg. & - & - & - & - \\
\hline Neg. & $6(1 \mathrm{M}, 5 \mathrm{~F})$ & Neg. & - & - & - & - \\
\hline Neg. & $3(0 \mathrm{M}, 3 \mathrm{~F})$ & Neg. & - & - & - & - \\
\hline Neg. & - & - & - & - & $2(1 \mathrm{M}, 1 \mathrm{~F})$ & Neg. \\
\hline Positives $=10$ & $113(20 \mathrm{M}, 93 \mathrm{~F})$ & $\begin{array}{l}\text { Positives }=33.33 \% \\
(8 / 24 \text { pools })\end{array}$ & $71(21 \mathrm{M}, 50 \mathrm{~F})$ & $\begin{array}{l}\text { Positives }=33.33 \% \\
(5 / 15 \text { pools })\end{array}$ & $13(5 \mathrm{M}, 8 \mathrm{~F})$ & $\begin{array}{l}\text { Positives }=0.00 \% \\
(0 / 7 \text { pools })\end{array}$ \\
\hline
\end{tabular}

Pos. = positive for B. alsatica; Neg. = negative for B. alsatica. $\mathrm{M}=$ male; $\mathrm{F}=$ female; $O$. cuniculus: Oryctolagus cuniculus; $S$. cuniculi: Spilopsyllus cuniculi; $X$. cunicularis: Xenopsylla cunicularis; O. quirosi: Odontopsyllus quirosi.

\section{Ethical approval}

Ethical approval was given by the Universidad de Jaén Research Ethics Committee for the data collection. These approvals covered the extensive research protocols that were needed for sampling in the field and develop work at the molecular biology laboratory.

\section{Results and discussion}

Eventually, all quality control assays performed on DNA of wild rabbit or fleas were positive. Overall, PCR amplicons positive for $B$. alsatica were obtained from 10 rabbits and 8/24 pools of $S$. cuniculi and 5/15 pools of $X$. cunicularis (Table 1). The 7 pools tested for O. quirosi were negative. All flea pools positive against $B$. alsatica were collected from positive rabbits. In three positive rabbits a pool of $S$. cuniculi and two pools of $X$. cunicularis respectively were negatives. After sequencing, only Bartonella alsatica was found in rabbit as well than in $S$. cuniculi and X. cunicularis fleas tested.

The sequences gathered for this study were further compared with other homologous sequences for B. alsatica previously accesed in GenBank (AF312506 and HM060955) and found to have a $100 \%$ amplicon homology with AF312506.

The molecular evidence depicts the persistence of $B$. alsatica in two rabbit flea species and shows that at least two of the five fleas evolutionary related with European rabbit, Spilopsyllus cuniculi and Xenopsylla cunicularis may have a role in the spread of B. alsatica among natural populations of wild rabbit, and possibly may be involved in the transmission of these bacteria to humans. 
The study confirms the implication of at least two fleas in the transmission cycle of B. alsatica in European wild rabbit. In Andalusia, European wild rabbits have previously been found to be parasitized by 4 species of flea. Preliminary data indicates that at least 2 of these species (S. cuniculi and X. cunicularis) can contribute to maintain the transmission cycle of $B$. alsatica in nature. Two previous reports indicate molecular detection of B. alsatica from $S$. cuniculi fleas from a European wildcat (Felis silvestris silvestris) in Andalusia, Spain [19] and from wild rabbits from southern France [23] using PCR and sequencing. In rabbits and fleas studied, we found a DNA sequence homologous to AF312506, with a length of 1273 bases [24], whereas other authors [20] described a sequence of 576 bases in length (accession code HM060955) of B. alsatica infecting S. cuniculi, which overlap with AF312506 between bases 399 and 993. The main difference between both Genbank accessed sequences is the deletion in HM060955 of the track TCTTATGAATTTATTTATA between positions 696 to 714 of AF312506 (97\% homology) in HM060955. We consider that the prevalence of such variant in rabbits is very low in South Spain (less than 1\%) [17]. A phylogenetic tree considering phylogenetic relations among B. alsatica and other Bartonella species appears in [23].

Other fleas species tested from several species of rabbit main predators (red foxes, dogs, cats, wild cats or lynxes) of the same environments such Pulex irritans, Ctenocephalides canis and Ct. felis were negative for $B$. alsatica [19]. In this study only $S$. cuniculi from wild cats has been positive for $B$. alsatica, although in this case, it seems likely that these fleas come from rabbits predated by this feline.

In the Iberian Peninsula, the population dynamics of these two flea species show clear differentiated peaks of abundance. Adults of $S$. cuniculi were found largely parasitizing rabbits in spring, though $X$. cunicularis is more abundant on rabbits in summer [14,25], whereas the larvae of wild rabbit fleas shares the same rabbit burrows [26]. The reproductive cycle of $S$. cuniculi depend on the reproductive cycle of it host in relation with hormone availability $[27,28]$. Frequently adults of both species can be recovered from rabbits as well in several rabbit predators $[19,29]$.

The overlapping and succession in time of these two fleas species as adult (or as larvae in the rabbit burrows) can explain the maintaining of Bartonella alsatica in rabbit population over the year. There is evidence to suggest Ctenocephalides felis faeces contains Bartonella henselae [30], and recently, it had been demonstrated that gut voids from the digestive tract of Bartonellapositive Xenopsylla ramesis contained Bartonella DNA [31]. On the other hand, the larvae of the flea Parapulex chephrenis include in its diet, faeces and voids from adult flea as well as other materials [32]. Ingestion of fomites by flea larvae could constitute a nontraditional vertical nontransovarial proper infection source for uninfected flea larvae and may contribute to maintain these vectorial cycles in natural conditions [33], contrary what occurs in the case of others pathogens transmitted by fleas [34].

\section{Conclusions}

The data points towards the action of two pulicidae flea species, S. cuniculi and X. cunicularis (as adults or as larvae), in the maintenance of infection by $B$. alsatica in wild rabbit populations throughout the year $[35,36]$.

More work is needed to confirm that those or other rabbit parasitizing flea species are involved in $B$. alsatica transmission as well as determining in such cases, if infection of flea can occur at larval stage (e.g. via ingestion of contaminated blood contained in flea faeces or in gut voids from non-necessarily conspecific adult flea) or if it is a consequence of adult flea feeding upon a bacteremic host.

Future research will be needed to study the epidemiology of B. alsatica and other Bartonella in Andalusia as well as their association with infections in European wild rabbit, its fleas and humans, furthermore to discern if $B$. alsatica could be responsible for human cases with unknown fever or febrile illness in Iberian Peninsula.

\section{Competing interests}

The author declares that he has no competing interests.

\section{Acknowledgments}

This project was partially supported by a grant from the Universidad de Jaen Research Program (2008/Acción 16). We thank Dr. Ricardo A. Oya, from the Research Technical Services (CICT) of Jaén University, for support in sequencing. I am very grateful to PhD Alex Steel, Salford University, for their help in the revision of this manuscript.

Received: 9 July 2014 Accepted: 16 January 2015

Published online: 27 January 2015

\section{References}

1. Bitam I, Dittmar K, Parola P, Whiting MF, Raoult D. Fleas and flea-borne diseases. Int J Infect Dis. 2010;14:e667-76. Available from: doi:10.1016/j.jijid.2009.11.011.

2. Eisen RJ, Gage KL. Transmission of flea-borne zoonotic agents. Annu Rev Entomol. 2012;57:61-82. doi:10.1146/annurev-ento-120710-100717.

3. Chomel BB, Boulouis HJ, Breitschwerdt EB, Kasten RW, Vayssier-Taussat M, Birtles RJ, et al. Ecological fitness and strategies of adaptation of Bartonella species to their hosts and vectors. Vet Res. 2009;40:29.

4. Heller R, Kubina M, Mariet P, Riegel P, Delacour G, Dehio C, et al. Bartonella alsatica sp. nov., a new Bartonella species isolated from the blood of wild rabbits. Int J Syst Bacteriol. 1999:49:283-8.

5. Raoult D, Roblot F, Rolain JM, Besnier JM, Loulergue J, Bastides F, et al. First isolation of Bartonella alsatica from a valve of a patient with endocarditis. J Clin Microbiol. 2006;44:278-9. Available from: doi:10.1128/JCM.44.1.278-279.2006.

6. Angelakis E, Lepidi H, Canel A, Rispal P, Perraudeau F, Barre I, et al. Human case of Bartonella alsatica lymphadenitis. Emerg Infect Dis. 2008;14:1951-3.

7. Jeanclaude D, Godmer P, Leveiller D, Pouedras P, Fournier PE, Raoult D, et al. Bartonella alsatica endocarditis in a French patient in close contact with rabbits. Clin Microbiol Infect. 2009:15 Suppl 2:110-1.

8. Kent RJ. Molecular methods for arthropod bloodmeal identification and applications to ecological and vector-borne disease studies. Mol Ecol Resour. 2009;9:4-18. Avalible from: doi:10.1111/j.1755-0998.2008.02469.x. 
9. Reeves WK, Rogers TE, Durden LA, Dasc GA. Association of Bartonella with the fleas (Siphonaptera) of rodents and bats using molecular techniques. J Vector Ecol. 2007;32:118-22.

10. Beaucournu JC. Les puces du Lapin de Garenne, Oryctolagus cuniculus (L.). In: Traub R, Starcke H, editors. Proceedings of International Conference on Fleas: 21-25 June 1977; Ashton Wold/Peterborough/UK. Rotterdam: A. A. Balkema; 1980. p. 383-9.

11. Beaucournu JC, Launay H. Les puces de France et du Bassin Méditerranéen Occidental. Paris: Federation Française des Societés de Sciences Naturelles; 1990

12. Márquez FJ. Relations de similitude entre les espèces de tiques du Lapin de garenne, Oryctolagus cuniculus (L.). Bull Soc Franç Parasitol. 1991;9:271-8.

13. Ferrand N, Branco M. The evolutionary history of the European rabbit (Oryctolagus cuniculus): major patterns of population differentiation and geographic expansion inferred from protein polymorphism. In: Weiss $\mathrm{S}$, Ferrand N, editors. Phylogeography in Southern European Refugia: Evolutionary Perspectives on the Origins and Conservation of European Biodiversity. Amsterdam: Springer; 2007. p. 207-35.

14. Launay H. Données préliminaires sur l'écologie de Xenopsylla cunicularis Smit, 1957 (Siphonaptera, Pulicidae) parasite du lapin de garenne. Ann Parasitol Hum Comp. 1982;57:145-63.

15. Cooke BD, Skewes MA. The effect of temperature and humidity on the survival and development of the European rabbit flea Spilopsyllus cuniculi (Dale). Austral J Zool. 1988;36:449-59.

16. Cooke BD. Rabbit burrows as environments for the European rabbit fleas, Spilopsyllus cuniculi (Dale), in arid South Australia. Austral J Zool. 1990;38:317-25

17. Márquez FJ. Molecular detection of Bartonella alsatica in European wild rabbits (Oryctolagus cuniculus) in Andalusia (Spain). Vector Borne Zoonotic Dis. 2010;10:731-4. Available from: doi:10.1089/vbz.2009.0135.

18. Rolain JM, Franc M, Davoust B, Raoult D. Molecular detection of Bartonella quintana, B. koehlerae, B. henselae, B. clarridgeiae, Rickettsia felis, and Wolbachia pipientis in cat fleas, France. Emerg Infect Dis. 2003;9:338-42. Available from: doi:10.3201/eid0903.020278.

19. Márquez FJ, Millán J, Rodríguez-Liébana JJ, García-Egea I, Muniain MA. Detection and identification of Bartonella sp. in fleas from carnivorous mammals in Andalusia, Spain. Med Vet Entomol. 2009;23:393-8. Available from: doi:10.1111/j.1365-2915.2009.00830.x.

20. Folmer O, Black M, Hoeh W, Lutz R, Vrijenhoek R. DNA primers for amplification of mitochondrial cytochrome c oxidase subunit I from diverse metazoan invertebrates. Mol Mar Biol Biotechnol. 1994;3:294-9.

21. Hall TA. BioEdit: a user-friendly biological sequence alignment editor and analysis program for Windows 95-98-NT. Nucleic Acids Symp Ser. 1999:41:95-8.

22. Altschul SF, Gish W, Miller W, Myers EW, Lipman DJ. Basic local alignment search tool. J Mol Biol. 1990;215:403-10.

23. Kernif T, Parola P, Ricci JC, Raoult D, Rolain JM. Molecular detection of Bartonella alsatica in rabbit fleas, France. Emerg Infect Dis. 2010;16:2013-4. Available from: doi:10.3201/eid1612.100696.

24. Houpikian P, Raoult D. 16S/23S rRNA intergenic spacer regions for phylogenetic analysis, identification, and subtyping of Bartonella species. J Clin Microbiol. 2001;33:2768-78. doi:10.1128/JCM.39.8.2768-2778.2001.

25. Osácar JJ, Lucientes J, Calvete C, Peribañez MA, Gracia MJ, Castillo JA. Seasonal abundance of fleas (Siphonaptera: Pulicidae, Ceratophyllidae) on wild rabbits in a semiarid area of northeastern Spain. J Med Entomol. 2001;38:405-10.

26. Osácar-Jiménez JJ, Lucientes-Curdi J, Calvete-Margolle C. Abiotic factors influencing the ecology of wild rabbit fleas in north-eastern Spain. Med Vet Entomol. 2001;15:157-66. doi:10.1046/j.1365-2915.2001.00290.x

27. Mead-Briggs AR. A correlation between development of the ovaries and of the midgut epithelium in the rabbit flea Spilopsyllus cuniculi. Nature. 1964:201:1303-4

28. Rothschild M, Ford B. Maturation and egg-laying of the rabbit flea (Spilopsyllus cuniculi Dale) induced by the external application of hydrocortisone. Nature. 1964;203:210-1.

29. Millán J, Ruiz-Fons F, Márquez FJ, Viota M, López-Bao JV, Paz Martín-Mateo M. Ectoparasites of the endangered Iberian lynx Lynx pardinus and sympatric wild and domestic carnivores in Spain. Med Vet Entomol. 2007:21:248-54. Available from doi:10.1111/j.1365-2915.2007.00696.x.
30. Higgins JA, Radulovic S, Jaworski DC, Azad AF. Acquisition of the cat scratch disease agent Bartonella henselae by cat fleas (Siphonaptera: Pulicidae). J Med Entomol. 1996;33:490-5.

31. Morick D, Krasnov BR, Khokhlova IS, Gottlieb Y, Harrus S. Investigation of Bartonella acquisition and transmission in Xenopsylla ramesis fleas (Siphonaptera: Pulicidae). Mol Ecol. 2011;20:2864-70. Available from doi:10.1111/j.1365-294X.2011.05033.x.

32. Krasnov BR, Sarfati M, Arakelyan MS, Khokhlova IS, Burdelova NV, Degen AA. Host specificity and foraging efficiency in blood-sucking parasite: feeding patterns of the flea Parapulex chephrenis on two species of desert rodents. Parasitol Res. 2003;90:393-9.

33. Morick D, Krasnov BR, Khokhlova IS, Gutiérrez R, Gottlieb Y, Harrus S. Vertical nontransovarial transmission of Bartonella in fleas. Mol Ecol. 2013;23:4747-52. Available from doi:10.1111/mec.12408

34. Thepparit C, Hirunkanokpun S, Popov VL, Foil LD, Macaluso KR. Dissemination of bloodmeal acquired Rickettsia felis in cat fleas, Ctenocephalides felis. Parasit Vectors. 2013;6:149. Available from doi:10.1186/1756-3305-6-149.

35. Cooke BD. Notes on the comparative reproductive biology and the laboratory breeding of the rabbit flea Xenopsylla cunicularis Smit (Siphonaptera, Pulicidae). Austral J Zool. 1990;38:527-34.

36. Cooke BD. Notes on the life history of the rabbit flea Caenopsylla laptevi ibera Beaucornu \& Márquez, 1987 (Siphonaptera: Ceratophyllidae) in eastern Spain. Parasite. 1999:6:347-54.

\section{Submit your next manuscript to BioMed Central and take full advantage of:}

- Convenient online submission

- Thorough peer review

- No space constraints or color figure charges

- Immediate publication on acceptance

- Inclusion in PubMed, CAS, Scopus and Google Scholar

- Research which is freely available for redistribution 